\title{
How system-internal linguistic factors indicate language change and diffusion. A geolinguistic analysis of Berber data
}

\author{
Mena Lafkioui
}

\begin{abstract}
This article discusses how language change and diffusion in Tarifit (Rif-Berber, North Morocco) can be explained by system-internal factors. The examined cases examined concern several innovation processes triggered by the vocalisation phenomenon of the liquids $/ \mathrm{r} /$ and $/ \mathrm{r} /$ and involving both phonological and morphological features and structures. The analyses presented analyses confirm that innovation can also be formally motivated, which refutes Croft's (2000: 38) claim that only functional factors can induce language change. Moreover, they show how functional properties may determine the success of the diffusion of variants. As such, they offer evidence against the claim that only social factors are accountable for variant selection (Milroy 1992: 201-202; Croft 2000: 38, 54). The considered data considered in this contribution come from the Atlas Linguistique des variétés berbères du Rif (Lafkioui 2007), a geolinguistic study of the Berber varieties of North Morocco.
\end{abstract}

\section{Introduction}

In this article, I examine how certain phonological and morphological innovation processes triggered by the vocalisation of the liquids $/ r /$ and $/ \mathrm{r} /$ in Tarifit (Rif-Berber) create language variation and change. Furthermore, I address how formal and functional features may affect the diffusion of these new variants. In doing so, I offer evidence against the claim that only social factors determine the success of the diffusion of variants (Milroy 1992: 201-202; Croft 2000: 38, 54) and confirm the importance of formal-driven language change (Seiler 2006).

All analyses in this contribution are based on data from the Atlas Linguistique des variétés berbères du Rif (Lafkioui 2007), a geolinguistic study of the Berber varieties of North Morocco. These varieties - often grouped under the collective term "Tarifit" - belong to the Northern Berber language group. They are delimited in the west by the varieties of Ktama (also called Senhaja varieties), in the south by the koine of Gersif (last point before the corridor of Taza) and in the east by the varieties of the Iznasen, which are in direct contact with Arabic varieties near the Algerian border (cf. Fig. 1). Besides the complex phonological processes that affect its mor- 
phological structure, Tarifit is also characterised by a large amount of dialect variation.

From a typological perspective, the Berber languages, belonging to the Afro-asiatic phylum, are predominantly synthetic (inflection, derivation and compounding) and flective. Common features are their VSO base word order, their pro-drop feature (verbal constructions obligatorily contain an incorporated subject marker), their preposition-noun sequence, their possessive suffixes and their mixed morphological plural formation (affixation and/or apophony). Aside from noun-verb oppositions, all other word class distinctions are unclear in Berber.

An examination of the vocalisation phenomenon of the liquids $/ r /$ and $/ \mathrm{r} /$ in Tarifit follows this introduction (Sections 2, $3 \& 4$ ). In Section 5, two "alternative" vocalisation processes are considered: the vocalisation of the liquids $/ \mathrm{r} /$ and $/ \mathrm{r} /$ in onset position and the vocalisation of the transformed liquid $/ 1 /(/ \mathrm{r} \Leftarrow 1 /$ or $/ \hat{r} /)$. The morphological implications of these synchronic and diachronic transformations are analysed in Section 6. The article ends with a number of conclusions about language variation and its connection with language diffusion and evolution.

\section{Vocalisation of the liquids $/ \mathbf{r} /$ and $/ \mathbf{r} /$ and the vowel system of Tarifit}

One of the central features that distinguish Tarifit from the other Berber languages is its vowel system, which displays a remarkable complexity historically engendered by the vocalisation of the liquids $/ r /$ and $/ r /$. This vocalisation process has led to a series of diachronic transformations with a major phonological impact. Most Berber languages have the following three basic vowels:

- Closed front vowel /i/ often pronounced as [I]; [IzI] 'fly'.

- Closed back vowel /u/ often pronounced as [u]; [ul] 'heart'.

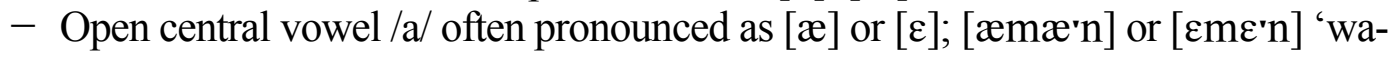
ter'.

Besides these vowels, the Berber languages also make use of the central vowel [ə], which is generally not considered a phoneme in Berber studies but an "epenthetic realisation feature" avoiding an accumulation of consonants.

Depending on the number of vowels composing their phonological systems, the Berber languages can be divided into:

- those with a basic system consisting of the vowels /i/, /u/ and /a/ (the majority);

- those with an extended system (the minority), to which belong Tarifit (Chtatou 1994; Louali \& Puech 1997, 1998; Louali-Raynal 2000; Lafkioui 2000, 2002, 2006a, 2007: 17, 29-37) and Tuareg (Prasse 1972; Louali-Raynal 2000). 
Chtatou (1994) and Louali-Raynal (2000) rightly point out that little attention has so far been paid to the vocalism of the Berber languages, at either a descriptive or an explanatory level, often leading to hasty and incorrect classifications of potential phonemes as allophones of the basic vowels.

\subsection{Vocalisation of the tap $|r|$ and the trill $|r|$}

The tap $/ \mathrm{r} /([\mathrm{r}])$ and the trill $/ \mathrm{r} /\left[\mathrm{r}^{\mathrm{i}}\right]$ are objects of vocalisation in several Tarifit varieties mostly in the Central Rif area (cf. Fig. 1: grey zones). Depending on the variety in question, this process has reached different stages. In function of the preceding vowel, these liquids are realised differently as shown in Tables 1 and 2.

With the exception of the long vowels [I:] and [U:] - which appear to be confined to the Ayt Weryagel (cf. Fig. 1: area with bold boundary) - all these phones occur in several varieties of the Central Rif area (Lafkioui 2007: 29-33; cf. Fig. 1).

Table 1: Forms of the vocalised $/ \mathrm{r} /$

\begin{tabular}{|c|c|}
\hline Diachronic form & $\begin{array}{l}\text { Synchronic form } \\
\text { Phonetic transcription }\end{array}$ \\
\hline \multirow{5}{*}{ ir } & [Ir] \\
\hline & [Ir] \\
\hline & {$\left[\varepsilon æ^{r}\right]$} \\
\hline & [عæ:] \\
\hline & [I: \\
\hline \multirow{5}{*}{ ur } & [Ur] \\
\hline & [Ur] \\
\hline & {$\left[\mathrm{oa}^{\mathrm{S}}\right]$} \\
\hline & [oa:] \\
\hline & {$[\mathrm{U:}]$} \\
\hline \multirow{4}{*}{ ar } & {$[\varepsilon r]$ or $[\mathfrak{e r}]$} \\
\hline & {$[\varepsilon r]$ or $[\mathfrak{r}]$} \\
\hline & {$\left[\varepsilon^{r}\right]$ or $\left[\mathfrak{P}^{r}\right]$} \\
\hline & [E:] or [æ:] \\
\hline \multirow{5}{*}{ er } & [ə厂] \\
\hline & {$[\varepsilon r]$ or $[æ r]$} \\
\hline & {$[\varepsilon r]$ or $[æ r]$} \\
\hline & {$\left[\varepsilon^{r}\right]$ or $\left[\mathfrak{Q}^{\mathrm{r}}\right]$} \\
\hline & [ع:] or [æ:] \\
\hline
\end{tabular}


Table 2: Forms of the vocalised /r/

\begin{tabular}{|c|c|}
\hline Diachronic form & $\begin{array}{c}\text { Synchronic form } \\
\text { (end stage) }\end{array}$ \\
\hline iṛ & {$\left[\mathrm{e}^{\mathrm{S}}:\right]$} \\
\hline ur & {$\left[0^{\Upsilon_{i}}:\right]$} \\
\hline aṛ & {$\left[\Lambda^{i_{i}}:\right]$} \\
\hline
\end{tabular}

This diachronic vocalisation process has caused an extension of the vowel system through the creation of units that are distinct from the basic vowels by their changed quality - an apparent compensatory lowering for [I:] and [U:] - and their considerable quantitative value due to compensatory lengthening.

Table 3: Long vowels resulting from the vocalisation of $/ \mathrm{r} /$ and $/ \mathrm{r} /$

\begin{tabular}{|c|c|c|}
\hline Diachronic Form & Synchronic Form & Phonetic Form \\
\hline ir & $\overline{1}$ & $\begin{array}{l}\text { diphthong [عæ:] } \\
\text { monophthong [I: }\end{array}$ \\
\hline ur & $\overline{\mathrm{u}}$ & $\begin{array}{l}\text { diphthong [oa:] } \\
\text { monophthong [U:] }\end{array}$ \\
\hline ar/er & $\overline{\mathrm{a}}$ & $\begin{array}{l}\text { monophthong }[\varepsilon:] \\
\text { monophthong [æ:] }\end{array}$ \\
\hline ir & $\overline{1}$ & monophthong $\left[\mathrm{e}^{\mathrm{S}_{\mathrm{i}}}\right]$ \\
\hline ur & $\bar{u}$ & monophthong $\left[\mathrm{O}^{\mathrm{i}} \mathrm{:}\right]$ \\
\hline ar & $\overline{\mathrm{a}}$ & monophthong $\left[\Lambda^{\mathrm{S}}:\right]$ \\
\hline
\end{tabular}

Examples from Ayt Temsaman (Central Rif):

(01) atbir $\left[\varepsilon \theta \beta I^{\prime} \Upsilon\right]$ or $\left[æ \theta \beta I^{\prime} \mathrm{c}\right]+$ vocalisation $\Rightarrow a \underline{t} \underline{b} \bar{i}[\varepsilon \theta \beta \varepsilon æ:]$ or $[æ \theta \beta \varepsilon æ:]$ 'pigeon'

(02) $u r \underline{t} u[v r \theta v]+$ vocalisation $\Rightarrow \bar{u} \underline{t} u[\mathrm{oa}: \theta v]$ 'fig tree'

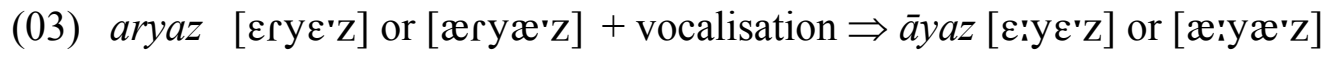
'man'

(04) $\underline{t} a r w a\left[\theta \Lambda \mathrm{r}^{\mathrm{f}} \mathrm{w} \varepsilon\right]+$ vocalisation $\Rightarrow \underline{t} \underline{\operatorname{a}} w a\left[\theta \Lambda^{\complement}: \mathrm{w} \varepsilon\right]$ 'children'

The long vowels $/ \overline{\mathbf{1}} /, / \overline{\mathrm{u}} /, \overline{\mathrm{a}} /$ and $/ \overline{\mathrm{a}} /$ are integrated into the phonological system of Tarifit because of their divergent phonetic value, their identification as distinctive units, the considerable functional return of the distinctive oppositions which they form and their high usage frequency (Lafkioui 2000, 2002, 2006a, 2007: 29-37). Hence, Tarifit's vowel system distinguishes seven phonemes including three basic vowels, three long vowels and one long and pharyngalised vowel (cf. Table 4). 
Table 4: Vowel System of Tarifit (Central Rif)

\begin{tabular}{|c|c|}
\hline Basic Vowels & Long Vowels \\
\hline $\mathrm{i}$ & $\overline{\mathrm{i}}$ \\
\hline $\mathrm{u}$ & $\overline{\mathrm{u}}$ \\
\hline $\mathrm{a}$ & $\overline{\mathrm{a}}$ \\
\hline & $\overline{\mathrm{a}}$ \\
\hline
\end{tabular}

There has been a long-standing debate about the status of these derivative vowels in Berber studies, which can be divided into two tendencies:

- The traditional tendency, which goes back to the beginning of the $20^{\text {th }}$ century and regards these vowels as unstable allophones of the basic vowels by historical and comparative reconstructions; the long vowels are thus not included here in the phonological system of Tarifit (Biarnay 1917; Renisio 1932; Chami 1979; Tangi 1991).

- The new tendency, which expands further the traditional historical and comparative findings but also describes and explains the data by synchronic and/or instrumental analysis, and on that ground accords these long vowels phonological status (Chtatou 1994; Lafkioui 2000, 2002, 2006a, 2007: 29-37; Louali \& Puech 1998; Louali-Raynal 2002).

With the exception of Tangi (1991), Dell \& Tangi (1993), Louali \& Puech (1997) and Louali-Raynal (2000, 2002), most Berber studies qualify these vowels as "long" (Biarnay 1917; Renisio 1932; Chami 1979; Cadi 1987; Chtatou 1982, 1994; Hamdaoui 1985; Allati 1986; Lafkioui 2000, 2002, 2006a, 2007). Nevertheless, their length differs according to region and speaker.

Even in the first linguistic descriptions of certain Tarifit varieties (Biarnay 1917; Renisio 1932), vocalisation was regarded as a part of the general phonetic transformation process of weakening of consonants (as in spirantisation: plosive - fricative - approximant - zero), which is an essential feature of Tarifit phonetics and phonology (Lafkioui 2006b, 2007: 38-58).

Phonetic economy is most likely the functional factor that has triggered this weakening process. The functional distribution of the new variants in the vowel system of Tarifit - in which the factor of transparency plays a pivotal role (disambiguating function) - is directly linked with the formal factor of phonological distinction (variants with or without distinctive value). However, this process has been driven in a specific direction by the formal restrictive rule which stipulates that vocalisation can only take place in the syllable coda:
(05) $\bar{i} \underline{d} n$
$\Leftarrow \quad i r \underline{d} n$
$(=\mathrm{ir}+\underline{\mathrm{dn}})$
'grain'
(06) $\underline{\text { tammūt }}$
$\Leftarrow$
tammurt
$(=\underline{\text { ta }}+$ mmurt $)$
'land'
(07) $a \underline{d} r \bar{a}$
$\Leftarrow a \underline{d r a r}$
$(=\mathrm{ad}+\mathrm{rar})$
'mountain'
(08) asādun
$\Leftarrow$
asrdun
$(=\mathrm{a}+\mathrm{sr}+\underline{\text { dun}})$
'mule' 
The fact that the vocalisation of $/ \mathrm{r} /$ and $/ \mathrm{r} /$ shows a homologous course of transformation points to two possible explanatory scenarios:

- the functional factor of "economy" has triggered both processes.

- the vocalisation of $/ \mathrm{r} /$ - occurring in a limited number of lexemes - is a formal development created by analogy with the vocalisation of $/ \mathrm{r} /$.

From a pan-Berber comparative perspective, the vocalisation of the liquids $/ \mathrm{r} /$ and $/ \mathrm{r} /$ is an idiosyncrasy, a specificity of the Central Rif area. It should be noted, however, that the vocalisation of the tap / $/$ / also occurs in Timimoun in the Gourara region (Algerian Sahara), but under other conditions: at the end of a lexeme $/ \mathrm{r} /$ disappears without leaving any trace and in preconsonantal position it transforms into $/ \mathrm{h} /([\mathrm{h}]), / \mathrm{h} /([\hbar])$ and $/ \varepsilon /([\mathrm{C}])$ (Boudot-Lamotte 1964).

Despite their limitedness, the data in Boudot-Lamotte (1964) indicate the small scale of this phenomenon in this area and its small systematic and productive character. Given the scanty and outdated linguistic data available on Timimoun, synchronic verifications in the field are necessary for a proper comparison with the Tarifit data. Nevertheless, one can reasonably suppose from the large geographical distance between these areas of North Africa that the extra-linguistic factor of "contact" did not instigate this innovation.

\section{Geographic diffusion of the vocalisation of the liquids $/ \mathrm{r} /$ and $/ \mathrm{r} /$}

In this section, I outline the principal features of the complex geographical diffusion of the vocalisation process of the liquids $/ r /$ and $/ r /$ in the Rif. The linguistic maps in Lafkioui (2007: 29-33) clearly display that this phenomenon is absent at the extremities of the Rif area (East Rif and West Rif) and in the vast majority of the varieties of the Ibeqquyen (Fig. 1, nr. 16), where $/ \mathrm{r} /$ and $/ \mathrm{r} /$ remain intact (cf. Fig 1, non-coloured zones). Everywhere else in the Rif region a variety of overlapping forms represent the different phases of vocalisation (gradual diffusion). The most advanced stage of vocalisation is detected in that group in which the liquids have completely disappeared (core area): Ayt Weryagel (in the majority of its varieties), Ayt Temsaman, Ayt Tuzin, Tafersit, Ayt Wlišek, North Igzennayen, West Ayt Scid and North-West Iqelciyen (cf. Fig 1, dark grey zones). With the exception of Ayt Weryagel, all varieties in this group generally display at the final stage the diphthong [عæ:] for the phoneme $/ \overline{1} /$, the diphthong [oa:] for $/ \overline{\mathrm{u}} /$, the allophones $\left[\varepsilon_{i}\right]$ or $[\mathfrak{:}]$ for $/ \overline{\mathrm{a}} /$ and the vowel $\left[\Lambda^{{ }}:\right]$for $/ \bar{a} /$. The Ayt Weryagel varieties, on the other hand, display a free variation between the

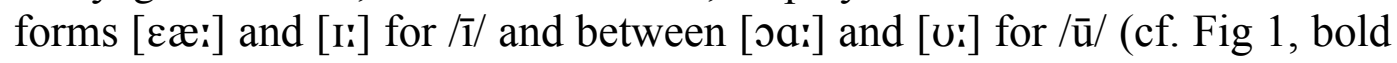
boundary). 
The varieties with the highest phonetic diversity for $/ \mathrm{r} /$ and $/ \mathrm{r} /$ are mostly located in contact areas: border zones such as the Ayt Buğay of the tribe Ayt Mezduy (border between West and Central Rif); transit areas such as the Izemmuren of the Ibeqquyen (Central Rif) and Zayyu of the Wlad Settut (East Rif); socio-economic centres such as Targist (West Rif) and Imezzužen of Ayt Nadur-Iqelciyen (East Rif). The strong linguistic variation in these geographical areas is largely attributable to increased and intensified contact, which constitutes an ideal engine of language change.

Since vocalisation occurs in one large region (Central Rif) and extends a considerable distance to the west and east, further than that indicated by data from the first Tarifit descriptions (Biarnay 1917; Renisio 1932), the new vowels are most likely engendered in a particular location from which several variants are distributed. The great size of the diffusion area points to social acceptance. There is no doubt that system-external (speaker-based) factors strongly determine the success of the diffusion of this innovation. However, the functional factors of economy and code conformity also contribute to the transmission of the vocalised variants. These linguistic factors may explain the absolute preference in the core area for complete vocalised variants, since these frequent forms cannot be directly associated with specific social functions and patterns such as status attribution.

\section{Vocalisation is a gradual linguistic process}

Vocalisation is a gradual process, not only at an extra-linguistic level (geographical and social diffusion) but also at a linguistic one: different transformation stages exist depending on the structure of the variety and the lexeme under consideration. System-based motivations for this type of gradual variation are mainly of a phonetic and morphological (cf. Section 6) nature.

A case of phonetic driven gradualism is the complementary link between $/ \mathrm{r} /$ and its vocalised variants: / $\mathrm{r} /$ can serve as a continuous glide sound when a long vowel precedes another vowel in a quickly articulated utterance, the former being reduced in quantity. The quantitative value of the resulting vowel, however, depends on the quantitative value of $/ \mathrm{r} /$.

Examples:

(09) awssā i d-yusin + high cadence $\Rightarrow$ awssar i d-yusin 'the old man who has come'

(10) awssā $i$ d-yusin + high cadence $\Rightarrow$ awssā y i d-yusin 'the old man who has come'

An important observation is that $/ \mathrm{r} /$ can serve as a glide only when the lexeme contains a historical $/ \mathrm{r} /$ in the coda (example 09). The semi-vowel / $\mathrm{y} /$, however, occurs as a glide both in lexemes which end with an etymological /r/ (example 10) and in those which do not (example 11):

(11) uma i $d$-yusin + high cadence $\Rightarrow$ uma y $d$-yusin 'my brother who has come' 
This connecting role of the liquid $/ \mathrm{r} /$ is widely observed in the vocalising Tarifit varieties. The semi-vowel / $y /$ functions as an optional glide variant of $/ r /$ in that zone of the Central Rif area in which vocalisation has reached the most advanced stage (mainly Ayt Weryagel, Ayt Temsaman and Ayt Tuzin of the core area). In several varieties of the Ayt Weryagel, this is in fact the most common practice. The fact that the semi-vowel /y/ has in these cases taken over the glide function of the etymological $/ \mathrm{r} /$ confirms the phonological status of the long vowels in Tarifit. ${ }^{1}$ A reinterpretation of the semi-vowel $/ y /$ as a glide in the phonetic context $[\overline{\mathrm{v}}+\mathrm{v}]$ by analogy with the glide function of $/ y /$ in the context $[v+v]$ has created this language change (formally triggered innovation).

\section{Alternative vocalisation}

Besides the basic vocalisations examined in Section 2.1., there are two "alternative" vocalisations in certain Berber varieties of the Central Rif area: the first process concerns the vocalisation of the liquids $/ r /$ and $/ r$ in onset position; the second concerns the vocalisation of the transformed liquid /1/ $(/ \mathrm{r} \Leftarrow 1 /$ or $/ \hat{\mathrm{r}} /)$.

\subsection{Vocalisation in onset position}

In the Ayt Weryagel varieties, vocalisation may occur in onset position, not without consequences for the phonetic, phonological and morphological structure of the lexemes in question (Lafkioui 2006a; 2007: 37). This alternative vocalisation occurs when the liquids are in both prevocalic and intervocalic positions:

Alternative vocalisation of $/ \mathrm{r} /$ in onset position:

- Prevocalic position:

\begin{tabular}{|c|c|c|c|c|c|}
\hline $\bar{i} d$ & {$[æ$} & & abrid & {$\left[æ \beta г I^{\circ}\right.$ ] } & 'way' \\
\hline $\bar{u}$ & & & rum & $\mathrm{m}]$ & br \\
\hline amqqān & [æmqqa:n] & $\Leftarrow$ & amqqran & [æmqqra’n] & big' \\
\hline
\end{tabular}

- Intervocalic position:

\begin{tabular}{|c|c|c|c|}
\hline 15) $\overline{l y}$ & [I:j] or [عæ:j] & $\Leftarrow i r i$ & [IrI] \\
\hline 6) $\bar{a} y$ & [æ:j] or [ $[\mathrm{ij}]$ & $\Leftarrow$ ari & [arI] \\
\hline 7) $\underline{d i} \dot{g} \bar{u} y$ & [ðıүU:j] & $\Leftarrow \underline{\text { digu}} u r i$ & [ðıуUгі] \\
\hline
\end{tabular}

\footnotetext{
${ }^{1}$ The semi-vowels $/ \mathrm{y} /$ and $/ \mathrm{w} /$ are the principal glides of Tarifit.
} 
(18) $\operatorname{imzg} \bar{a}(w) \quad[\mathrm{Imzj}: \mathrm{w}]$ or $[\mathrm{Imzj} \varepsilon: \mathrm{w}] \Leftarrow \operatorname{imzgura}$ [Imzjuræ] 'first ones' Alternative vocalisation of $/ \mathrm{r} /$ in onset position:

(19) $d \bar{u}(w) \quad\left[\mathrm{do}^{\mathrm{q}}:(\mathrm{w})\right] \quad \Leftarrow d u r u\left[\operatorname{dor}^{\mathrm{f}} \mathrm{o}\right] \quad$ 'duro', 'coin'

Alternative vocalisation of $/ \mathrm{r} /$ in onset and coda position (double vocalisation):

(20) $a \varepsilon \bar{u}$

$$
\text { [æYU:] or [æSoa:] } \Leftarrow \text { acrur [æSrur] 'back' }
$$

An interesting finding is that the vocalisation of the intervocalic $/ r /$ in onset position produces an extension of the first vowel and a disyllabification of the second vowel. The case of $\operatorname{imz} \bar{a} \bar{a}(w)$ 'first ones' (see example 18) is probably the result of this rule following a metathesis of $/ \mathrm{u} /$ and $/ \mathrm{a} /$ : imzgura $\Rightarrow i m z g a r u \Rightarrow \operatorname{imzg} \bar{a}(w)$. One might also consider this variant as the new plural structure imzg $\bar{a} \Leftarrow$ *imzgar, although the form *imzgar cannot be retrieved in Tarifit while the form imzgāw is freely and regularly alternated with imzgā.

In addition, Tarifit possesses a restrictive sub-rule according to which the vocalisation of $/ \mathrm{r} /$ cannot take place in an absolute Anlaut position before a vowel, as given in the following example:

(21) $* \bar{a} z \check{a} \Leftarrow$ raža 'wait' (Aorist-Imperative-Singular)

Hence, vocalisation in onset position provides for a syllabic restructuring of the lexeme, usually accompanied by a reduction of the number of syllables, principally in intervocalic position. This is a formal adaptation strategy of two possible innovation types:

- A functional triggered innovation in which the economy principle is driven to extremes.

- A formal triggered innovation in which analogy is made between vocalisation in onset position and vocalisation in coda position.

It should be noted that this alternative vocalisation is socially accepted in the varieties of the Ayt Weryagel (Section 5.3.) even though it affects the very basic lexical structure of Tarifit and therefore may hinder the intelligibility of the message (Lafkioui, 2007a : 37).

\subsection{Vocalisation of the mutated liquid /l/}

The alternative vocalisation in onset position is in co-variation with another diachronic phenomenon. That is the phonetic mutation of the lateral approximant $/ 1 /$ in $/ \mathrm{r} \Leftarrow 1 /$ or $/ \hat{\mathrm{r}} /$ (see Lafkioui 2007: 69-71), as follows:

$-/ \mathrm{r} \Leftarrow 1 /=$ voiced tap $[\mathrm{r}]$ with an ultra light friction; similar articulation as $/ \mathrm{r} /$ on a perceptive level

$=$ voiced trill $[\mathrm{r}]$

$-/ \hat{\mathrm{r}} / \quad=$ fricative $[1]$ 
The phonetic difference between the tap obtained from the mutation of $/ 1 /$ (/r $\Leftarrow 1 /$ with ultra light friction) and the original tap $(/ \mathrm{r} /$ without friction) is very difficult to detect. The friction of the former is so weak that it allows no distinction on a perceptive level. This explains why some scholars working on varieties that have only the two taps $/ \mathrm{r} /$ and $/ \mathrm{r} \Leftarrow 1 /$ and not the fricative $/ \hat{r} /$ conclude that there is no phonetic difference between these taps (Chtatou 1994: 184-187; Tangi 1991: 119). As regards the variety of Ayt Sidar (Iqelciyen), the surveys in Lafkioui (2007) present findings contrasting with the data in Tangi (1991: 119), because in this region the fricative $/ \hat{r} /$ is also used as a free variant of the tap $/ \mathrm{r} \Leftarrow 1 /$. It is understood that this distinction problem does not arise when it comes to the trill [r].

However, the difference between the two taps becomes more apparent when vowels precede them: $/ \mathrm{v} /+/ \mathrm{r} \Leftarrow 1 / \neq / \mathrm{v} /+/ \mathrm{r} /$; only the tap $/ \mathrm{r} /$ has a lowering effect on the vowels that it follows. Examples:

(22) ari $\Leftarrow$ ali 'climb':

(23) ari $\Leftarrow$ ari 'write':

[æг $]$ of $[\varepsilon \Gamma \mathrm{I}] \neq$

[ari]

These consonant mutations, primarily found in the Central Rif area, ${ }^{2}$ are in direct correlation with the phonetic restriction that excludes the vocalisation of $/ \mathrm{r} /$ obtained from $/ 1 /$. However, the varieties of the Ayt Weryagel are an exception to this rule; $/ \mathrm{r} \Leftarrow 1 /$ can indeed be vocalised, following a course of evolution analogous to $/ \mathrm{r}$, with long diphthongs as maximum transformations.

Examples of alternative vocalisation of transformed /1/ are:

Ayt Werya $\times$ el (Central Rif):

(24a) $/$ irs $([\mathrm{Irs}],[\mathrm{Irs}]) \Leftarrow i l s /+$ vocalisation $/ \mathrm{r} / \Rightarrow$ [عæ:s], [jeæ:s] and [ijeæ:s] 'language', 'tongue'

(24b) /irs ([Irs], [Irs]) $\Leftarrow i l s /+$ maintain /r/ $\Rightarrow$ [Irs], [Irs] 'language', 'tongue'

Ayt Wlišek and Iqelciyen (Central Rif):

(24c) $/$ irs $\Leftarrow i l s / \quad+$ maintain $/ \mathrm{r} / \Rightarrow$ irs $\quad$ ([Irs], [Irs] 'language', 'tongue')

(24d) $/ i \hat{r} s \Leftarrow i l s / \quad+$ maintain $|\hat{r}| \Rightarrow i \hat{r} s \quad$ ([Ils] 'language', 'tongue')

This type of alternative vocalisation extends the general vocalisation process through analogue transformation courses. Once again, we see systembased factors (economy and/or analogy) generating significant linguistic developments considered unacceptable outside the Ayt Weryagel and some adjacent varieties (cf. 5.3.).

\footnotetext{
${ }^{2}$ In the Western Rif area, different consonant mutations occur. These are $/ 1 / \Rightarrow /-\check{z} /$ ([3]) and $/ y /([j])$. The mutation discussed in this subsection is absent in the Eastern Rif varieties (Lafkioui 2007: 69-71).
} 


\subsection{Geographic diffusion of alternative vocalisation}

The above two alternative vocalisations are language processes in which the functional trigger of "economy" exerts such a strong pressure that the functional properties of "transparency" and "intelligibility" - of crucial importance for the form-function balance of language structure - are in jeopardy. From a formal perspective, these innovations have a great impact and are sometimes even pernicious because of their significant eroding effect on the basic syllable and lexeme structure of Tarifit. Nevertheless, these negative side effects do not deter speakers of the Ayt Weryagel from adopting the new variants. Onset-vocalisation in particular has had remarkable success in this region. Code conformity is a probable functional explanation for this trend. However, in some recent cases of vocalisation in onset position, formal factors also play an important role in their development and diffusion. For example, the new form ag $\bar{u} m$ ( $\Leftarrow$ agrum 'bread') - mostly encountered among children and adolescents - is an extension by analogy with abi $\underline{i} \underline{d}(\Leftarrow$ abrid 'way') and amqqān ( $\Leftarrow$ amqqran 'big'). The latter are long-established vocalisation cases: they occur among older generations, including speakers with nearly a century of language experience who claim always to have known this language practice as such, even among their parents. Accordingly, it seems clear that these innovations are system-based; their creation and diffusion is formally motivated (extension by analogy), just as with the older alternative vocalisations $a \underline{b} \underline{i} \underline{d}$ and amqqān (functional and/or formal trigger). An additional important finding is that alternative vocalisation is relatively recent but very productive. It operates on both Berber data and loan words (old and more recent loans) with a high usage frequency.

My linguistic and sociolinguistic surveys in this area (since 1992) also indicate the importance of a number of system-external factors for the diffusion of these innovations. ${ }^{3}$ Alternative vocalisation has a remarkable geographical and demographical expansion from the varieties of Ayt Buciyya-š (advanced stage) and Imzuren, two villages of the Ayt Weryagel in full development thanks to their recent increased economic activity (trade, transport), their favourable and central geographical location (trade and passage zones) and substantial financial investments from Rif-Berbers abroad. The rapid social extension of this phenomenon is primarily due to the intense

\footnotetext{
${ }^{3}$ The findings presented in this section are based on an examination of the vocalisation of $/ \mathrm{r} /$ and $/ \mathrm{r} /$ in Tarifit conducted in the context of several linguistic and sociolinguistic studies on Tarifit since 1992, including the geolinguistic study Atlas Linguistique des variétés berbères du Rif. I have followed up the recent evolution of this phenomenon by means of a series of (socio)linguistic and ethnographic surveys (directed and semi-directed, recorded on tape or minidisk) in which various parameters such as sex, age, social and economic class, ethnicity, education and mobility are taken into account.
} 
social contacts in these small but busy socio-economic centres, where local schools are one of the main contact and diffusion centres. Many of these alternative vocalisations have recently been created among children and teenagers from this region, who until recently were reprimanded by adults for their non-normative language use. Meanwhile, several generations of speakers (sometimes even the grandparents) of most varieties of the Ayt Weryagel and several neighbouring varieties have adopted these language practices (especially onset-vocalisation), though not always for the same lexemes and to the same degree (gradual diffusion).

\section{Morphological implications of vocalisation}

The vocalisation phenomenon described above has caused a number of significant morphological transformations, which include a restructuring of certain morphological patterns. In this section, I address these, with special reference to the Tarifit verbal and nominal system.

\subsection{Innovations in the verbal system of Tarifit}

6.1.1. The Berber verbal system. The Berber verbal system is of a RootPattern type. It is structured around a complex aspectual hierarchical configuration with three levels, which are structurally more complex and semantically more specific as one ascends the hierarchy. It displays a predominance of tri-radical roots and makes use of both consonant length and intraradical vowel alternation (apophony) to indicate aspectual categories. From a synchronic perspective, the Berber verbal form is composed of a stem and a personal marker (PM) or participle marker (PARTM). The stem itself consists of a consonantal root, which refers to a central semantic value, and a vowel pattern that orientates or specifies this value:

1. Verb $=$ stem + person or participle marker (highest level)

2. Stem $=$ root + vowel pattern (middle level)

3. Root $=$ consonantal radicals (basic level)

Verbal form:

(25a) $y$-ud $f$ [juðəf] 'he has entered' (PERF-3ms) = PM $y$ - (3ms) + stem -ud $f$ [ひðəf]

(26a) $y-u d f-n$ [juðfən] 'has/have entered' (PERF-part) = PARTM $y-e n+$ stem $-u \underline{d} f-[\mathrm{v} \mathrm{f}]$

Stem:

(25b) $-u \underline{d} f[$ [ひðəf] $=$ root / $\underline{\mathrm{d}} \mathbf{f} /$ (action 'to enter') + pattern /u--/ (PERF)

(26b) $-u \underline{d} f-[\mathrm{\partial f}]=\operatorname{root} / \underline{d} \mathbf{f} /$ (action 'to enter') + pattern /u--/ (PERF) 
Root:

(25c) Bi-radical root /cc/ with / $\mathrm{d} /$ [ð] and /f/ [f] as radicals (action 'to enter') (26c) Bi-radical root /cc/ with / $/$ / [ð] and /f/ [f] as radicals (action 'to enter')

Stem and person/participle marker are inevitably connected in the verbal syntagm; the former functions as predicate and the latter as subject. The subject marker is encoded on the verb as a prefix and/or a suffix and is made explicit by postverbal lexical complements with specific features, e.g. construct state. The V(erb)-S(ubject) syntagm represents the minimal required structure of an assertion, which is expanded by an object $(\mathrm{O})$ in the case of transitive verbs and various other complements insofar as the morphosyntactic adequacy and the semantic sufficiency of the verbal stem permit, with a VSO basic word order.

The present Berber verbal system is based on a fundamental morphological opposition of Perfective (PERF) versus Imperfective (IMPERF) for the positive aspects and Perfective (PEFRF) versus Negative Perfective (NEGPERF) for the negative aspects (Basset 1952; Galand 1977; Cadi 1987: 59-65; Chaker 1989; Lafkioui 2007: 174-191).

6.1.2. Morphological innovations of the verb. The first morphological development triggered by the vocalisation of $/ \mathrm{r} /$ is the extension of verbal paradigms of the type /ccv/, /vcc/ and /cvc/ at the expense of /ccc/, despite the fact that this last is widely regarded as one of the main synchronic consonant verbal structures in Berber (Basset 1952; Galand 1977; Cadi 1987: 59-65; Chaker 1989; Lafkioui 2007: 174-191).

Examples:

(27) $/ \mathrm{ccc} /+$ vocalisation $\Rightarrow / \mathrm{ccv} / ; \quad m z ̌ r ~[\mathrm{~m} z ə r] \Rightarrow m z \check{a}[\mathrm{~m} z æ:]$ 'plough'

(28) $/ \mathrm{ccc} /+$ vocalisation $\Rightarrow / \mathrm{vcc} / ; \quad r w l \quad$ [rwəl] $\Rightarrow \bar{a} w l$ [a:wəl] 'run away'

(29) $/ \mathrm{ccc} /+$ vocalisation $\Rightarrow / \mathrm{cvc} /$; frn [frən] $\Rightarrow$ fān [fæ:n] 'sort'

Example (27) shows how $/ \mathrm{r} /$ is vocalised in coda position when preceded by the central vowel [ə]. In example (28) [ə] is inserted before $/ \mathrm{r} /$ :

$-[\mathrm{rw} \partial \mathrm{l}] \Rightarrow[$ ərwəl $] \Rightarrow[$ arwəl $] \Rightarrow \ldots \Rightarrow$ [a:wəl] $(\bar{a} w l)$

In the last illustration (29) the sequence [rə] undergoes a permutation under the influence of the sonority rule before vocalisation may occur:

- /cre/ $\Rightarrow /$ cer/ $\Rightarrow / \overline{\mathrm{v}} /$

[frən $] \Rightarrow[$ fərn $] \Rightarrow \quad[$ fe:n] or [fæ:n] $(f \bar{a} n)$

This reorganisation of the paradigmatic structure of the verb (phonologically triggered morphological changes) has engendered a number of interesting analogous morphological developments which involve two central and productive verbal aspect oppositions in Tarifit (and indeed in Berber in general). These are Perfective (PERF) Negative Perfective (NEGPERF) and Perfective $(\mathrm{PERF}) \sim$ Imperfective $(\mathrm{IMPERF})$. 
Firstly, verbs with a vocalised / $\mathrm{r} /$ as second or third consonant display for the Negative Perfective the base $/ \mathrm{c} \overline{\mathrm{v}} \mathrm{c} /$ or $/ \mathrm{cc} \overline{\mathrm{v}} /$ with $\overline{\mathrm{v}}$ as the same long vowel as in the Perfective. The examples fān 'sort' (e.g. 29) and $m \check{z} \bar{a}$ 'plough' (e.g. 27) are thus forms of both Positive and Negative Perfective, and thus different from the respective forms * fin 'sort' and * mžl 'plough', which would be expected here because the Negative Perfective of / $\mathrm{ccc} /-$ verbs (such as the non-vocalised forms frn and $m \check{z} r$, but also e.g. $h \underline{d} d m$ ) have /ccic/ as their base, as in frin 'sort', mžir 'plough' and hdim 'work'. The long vowels in these configurations are thus subject to morphological conditions different from the corresponding consonants (including $/ r /$ ) in the same position. ${ }^{4}$ In other words, this is a case of formal re-analysis of the bases $/ \mathrm{c} \overline{\mathrm{v}} \mathrm{c} /$ and $/ \mathrm{cc} \overline{\mathrm{v}} /$ of the Perfective as bases of the Negative Perfective, with $\overline{\mathrm{v}}$ as a long invariable vowel. The systematisation of these new variants with a morphologically unmarked base for the Negative Perfective may explain their widespread diffusion in the vocalising Tarifit varieties.

However, this diffusion is not wholesale. Rather, it displays a gradual pattern related to the following combinatorial opposition conditions:

$-m \check{z} \bar{a}$ (PERF) $\sim u r$ (NegMark) $+m \check{z} \bar{a}$ (NEGPERF, -mark); optional frequent opposition in varieties with complete vocalisation (core area)

- $m \check{z} \bar{a}$ (PERF) ur (NegMark) + mžir (NEGPERF, +mark); optional frequent opposition in all vocalisation areas

- $m \check{r}$ (PERF) ur (NegMark) + mžā (NEGPERF, -mark); optional frequent opposition in vocalisation areas

- mžr (PERF) ur (NegMark) + mžir (NEGPERF, +mark); obligatory opposition in areas without vocalisation

A second remarkable morphological innovation, in co-variation with the extension of verbal paradigms of the type /ccv/, / vec/ and /cvc/, is the diversification of the marking of the aspectual opposition Perfective $\sim$ Imperfective for verbs of the /ccc/-type with / $\mathrm{r}$ / as a central consonant.

Table 5: Perfective Imperfective Markers

\begin{tabular}{|c|c|}
\hline Perfective & Imperfective \\
\hline$/ \mathrm{r} /-f r n$ & $/ \mathrm{rr} /-f r r n$ \\
\hline & $/ \bar{a} r /-f \bar{a} r n$ \\
$\varnothing-f \bar{a} n$ & $/ \bar{a} r r /-f \bar{a} r r n$ \\
& $/ \mathrm{t}-/-t f \bar{a} n$ \\
& $/ \mathrm{t}-/+/ \bar{a} r /-t f \bar{a} r n$ \\
& $/ \mathrm{t}-/+/ \bar{a} r r /-t f \bar{a} r r n$ \\
\hline
\end{tabular}

\footnotetext{
${ }^{4}$ This morphologically triggered change also supports the phonological status of the long vowels.
} 
As is usual for /ccc/-verbs, the Imperfective of /crc/-verbs is generally marked by a duplication of the middle consonant. Because of the vocalisation of $/ \mathrm{r} /, / \varnothing /$ becomes the morphological marker of the Perfective. On the other hand, the morphemes /ār/ and /ārr/, resulting from the vocalisation of the geminated $/ \mathrm{rr} /$, indicate the Imperfective (on the vocalisation of the geminated liquid /rr/, see Lafkioui 2006a; 2007: 34). These morphemes can be combined with another Imperfective marker, the prefix $/ \mathrm{t}-/$, which may also be associated with the morpheme $/ \overline{\mathrm{a}} /$, as the final product of the vocalisation process of $/ \mathrm{rr} /$, as in tfān (Imperfective). Thus, the following solutions counterbalance the eroded aspect markers:

- new morphemes are created from vocalisation (/ø/ for PERF; /ār/ and /ārr/ for IMPERF);

- the existing IMPERF marker/t/ is prefixed to the base of the PERF without any changes;

- a combination of both developments (/t-/+/ār/ or /t-/+/ārr/ for IMPERF).

These new variants are therefore compensatory adjustments for eroded morphological configurations of the Perfective and the Imperfective. The structural adequacy of these specific and central morphophonemic oppositions has been a significant factor in their general diffusion in the vocalising Rif regions.

6.2.2. Innovations in the nominal system of Tarifit. The noun in Berber distinguishes the sub-categories gender (masculine/feminine), number (singular/plural) and state (free/construct state). Some remarkable features specific to Berber consist of the following (Lafkioui 2007: 97-115):

- Masculine nouns are predominantly marked by the initial vowel /a/ (free state) and feminine nouns by the discontinuous morpheme $/ \mathrm{t}$ $\mathrm{t} / \mathrm{s}$

- The construct state is a particular noun form defined by an alteration of the vowel of the first syllable, used in specific contexts of syntactic dependency, e.g. post-verbal subject noun complements and prepositional noun complements.

There is no consensus among Berber scholars about the existence of the adjective sub-category because, from a morphological perspective, it has identical features as the substantive. Even on a syntactic level, these two sub-categories have almost all combinatorial and functional characteristics in common. The only criterion that clearly differentiates them is their syntactic distribution; the adjective always follows the substantive.

Vocalisation also has important implications for the functioning and development of certain nominal paradigms of Tarifit. New adaptive paradigms have been created to fill the morphological gaps caused by vocalisation, with old paradigms being perpetuated or adapted to meet the new re- 
quirements of the nominal system. A phenomenon that illustrates and substantiates this claim is plural noun formation, as in the following examples from Ayt Weryagel:

(30a) awssā [æwəssæ:] + internal plural $\Rightarrow$ iwssura [Iwəssuræ] 'old men'

$\Rightarrow$ iwssuya [iwəssujæ] 'old men'

(30b) awssā [æwəssæ:] + external plural $\Rightarrow i w s s a ̄ n$ [iwəssæ:n] 'old men'

In these examples, two new plurals have appeared for the singular form awss $\bar{a}$ 'old man': the internal plural form iwssuya (30a) and the external plural form iwssān (30b).

The internal plural form iwssuya (30a) is developed from the corresponding singular form awss $\bar{a}$ by analogy with the morphological scheme of the most common form, iwssura. Note that this morphological innovation is not obtained from the vocalisation of $/ \mathrm{r} /$ in onset position of iwssura,

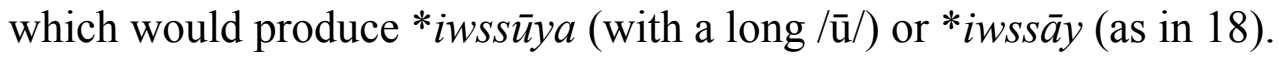

The external plural form iwssān (30b) is also directly derived from the singular form awss $\bar{a}$ but this time by affixation of the discontinuous plural morpheme /i $\mathrm{n} /$ and by analogy with current plurals such as $i \underline{t} \underline{\underline{a}} \bar{a} n(\Leftarrow$ itbarn 'pigeons'), because the form *iwssarn does not occur in Tarifit.

Both examples show how new plurals have been introduced into the nominal system of Tarifit by applying existing plural configurations to noncorresponding singular forms by analogy. This innovation mechanism is mainly observed in the varieties of the Ayt Weryagel (cf. Fig 1, area with bold boundary), which are characterised by their alternative vocalisations that profoundly affect the lexical structure of Tarifit (cf. Section 5). Morphological adequacy and generalisation of these plural configurations are important factors in explaining the diffusion of these innovations in this area.

\section{Conclusion}

The phonological and morphological phenomena engendered by vocalisation of the liquids $/ \mathrm{r} /$ and $/ \mathrm{r} /$ in Tarifit are examples of how language is constantly modulated in the form of innovations that may emerge in structurally layered and causal formations dictated by system-based properties. Additionally, several cases addressed in this article show that innovation can also be formally motivated. As such, they refute Croft's (2000: 38) claim that only functional factors can motivate language change.

It goes without saying that social factors are important for the diffusion of variants. However, the Berber data examined here demonstrate the nonnegligible share of certain system-internal factors in the diffusion of new phonetic/phonological and morphological items. Economy and code conformity are important functional motivations for the dispersal of the vocal- 
ised liquids in the Central Rif area. Structure adequacy and systematisation/generalisation of specific morphological patterns, however, play a significant role in the success of their distribution across the Tarifit varieties. Contrary to the language evolutionary claim that only social factors are responsible for variant selection (Milroy \& Milroy 1985; Milroy 1992: 201-202; Croft 2000: 38. 39. 54), the analyses here indicate how functional and social factors can interact in the selection and hence diffusion of language forms and how in some cases, as in the restructuring of the verbal paradigm, system-internal properties may dominate.

Another interesting finding which regularly pops up in this study is that language change is gradual not only on an extra-linguistic level (geographical and social variation) but also on a linguistic one. Therefore, it is important to consider the continuous selection process of variants not solely from a social perspective ("propagation" as in Croft 2000: 38. 178) but also in terms of how the variants are formally and functionally integrated into everchanging linguistic structures (cf. "implementation" in Seiler 2006).

\section{Bibliography}

Allati, Abdelaziz. 1986. Phonétique et phonologie d'un parler amazigh du NordEst marocain (le parler des Aït Saïd). Thèse de $3^{\mathrm{e}}$ cycle. Aix-en-Provence: Université de Provence.

Basset, André. 1952. La langue berbère. London: Oxford University Press.

Biarnay, Samuel. 1917. Etude sur les dialectes berbères du Rif (Ibeqqoyen, Ait Ouriaghel, Ait Touzin, Temsaman, Ikebdanen, Ait Itteft). Paris: Leroux.

Boudot-Lamotte, Antoine. 1964. Notes ethnographiques et linguistiques sur le parler berbère de Timimoun. Journal Asiatique 252, 487-558.

Cadi, Kaddour. 1987. Système verbal rifain. Forme et sens. Paris: SELAF.

Chaker, Salem. 1989. Aspect (verbe). In Encyclopédie berbère 7, 971-977.

Chami, Mohamed. 1979. Un parler amazigh du Rif marocain: approche phonologique et morphologique. Thèse du $3^{\mathrm{e}}$ cycle. Paris: Université de Paris-V.

Chtatou, Mohamed. 1982. Aspects of the phonology of a Berber dialect of the Rif. London: University of London/SOAS Ph.D. dissertation.

Chtatou, Mohamed. 1994. La représentation vocalique dans les dialectes berbères du Rif. Etudes et Documents berbères 11, 177-196.

Croft, William. 2000. Explaining Language Change: An Evolutionary Approach. Harlow: Longman.

Dell, François \& Ouafa Tangi. 1993. On the vocalisation of $/ \mathrm{r} /$ in ath-Sidhar Rifain Berber. Linguistica communicatio 5/1-2, 211-224.

Galand, Lionel. 1977. Continuité et renouvellement d'un système verbal: le cas du berbère. Bulletin de la Société de Linguistique 72/1, 275-303.

Lafkioui, Mena. 2000. Propositions pour la notation usuelle à base latine du rifain. Comptes rendus du Groupe Linguistique d'Études Chamito-Sémitiques 33, 189-200. 
Lafkioui, Mena. 2002. Le rifain et son orthographe : entre variation et uniformisation. In Caubet, Chaker \& Sibille (2002), Codification des langues de France, 355-366. Paris: L'Harmattan.

Lafkioui, Mena. 2006a. La vocalisation des alvéolaires /r/ et / $\mathrm{rr} /$ dans les variétés berbères du Rif. Studien zur Berberologie/Etudes Berbères 3, 175-184.

Lafkioui, Mena. 2006b. La spirantisation dynamique de la vélaire occlusive simple /k/ dans les varieties berbères du Rif. Studi berberi e mediterranei 3 (Nuova Serie), 219-228.

Lafkioui, Mena. 2007. Atlas linguistique des variétés berbères du Rif. Köln: Rüdiger Köppe Verlag.

Louali-Raynal, Naïma. 2000. Vocalisme berbère et voyelles touarègues. In Etudes berbères et chamito-sémitiques. Mélanges offerts à Karl-G. Prasse, 263-276. Paris/Louvain: Peeters.

Louali-Raynal, Naïma. 2002. Les mutations du 1 et du r pan-berbère. In Articles de linguistique berbère. Mémorial Werner Vycichl, 301-333. Paris: L'Harmattan.

Louali, Naïma \& Gilbert Puech. 1997. Le vocalisme en berbère rifain. Journées d'Etudes Linguistiques: La voyelle dans tous ses états 1997, 38-43.

Louali, Naïma \& Gilbert Puech. 1998. La partition de l'espace vocalique en berbère rifain. Actes des XXIIèmes Journées d'Etudes sur la Parole 1998, 83-85.

Milroy, James. 1992. Linguistic variation and change. Oxford \& Cambridge: Blackwell.

Milroy, James \& Milroy Lesley. 1985. Linguistic change, social network, and speaker innovation. Journal of Linguistics 21, 339-384.

Prasse, Karl G. 1972. Manuel de grammaire touarègue (tahaggart). Copenhague: Akademisk Forlag.

Renisio, Amédée. 1932. Etude sur les dialectes berbères des Beni Iznassen, du Rif et des Senhaja de Srair (Publications de l'Institut des Hautes Etudes Marocaines 22). Rabat : Publications de l'Institut des Hautes Etudes Marocaines.

Seiler, Guido. 2006. The role of functional factors in language change: an evolutionary approach. In: Nedergaard Thomsen, Competing Models of Linguistic Change. Evolution and beyond, 163-182. Amsterdam/Philadelphia: John Benjamins.

Tangi, Ouafa. 1991. Aspects de la phonologie d'un parler berbère du Maroc : AthSidhar (Rif). Université de Paris Thèse de Doctorat.

Mena Lafkioui • Ghent University • Università degli Studi di Milano-Bicocca • BELGIUM Mena.Lafkioui@UGent.be 


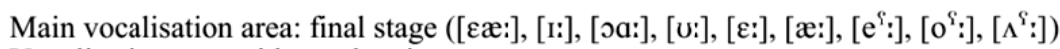
Vocalisation aera with overlapping stages

Area without vocalisation

Area of alternative vocalisation

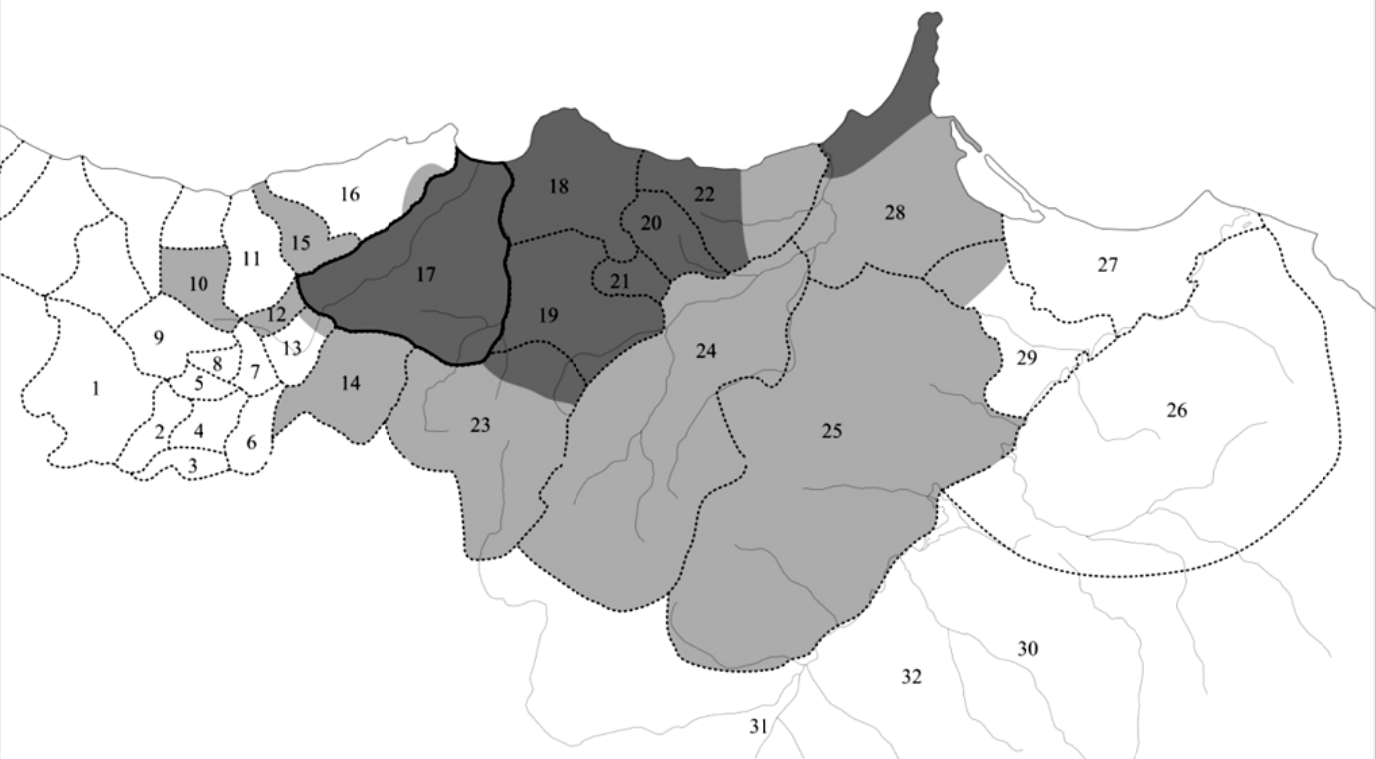

Fig. 1. Geographic diffusion of the vocalisation of the liquids $/ \mathrm{r} /$ and $/ \mathrm{r} /$ in the Rif (North Morocco)

$\begin{array}{ll}1 & \text { Ktama } \\ 2 & \text { Taġzut } \\ 3 & \text { Ayt Bušibet } \\ 4 & \text { Ayt Ḥmed } \\ 5 & \text { Ayt Bunsar } \\ 6 & \text { Ayt Bšir } \\ 7 & \text { Zerqet } \\ 8 & \text { Ayt Úennus } \\ 9 & \text { Ayt Seddat } \\ 10 & \text { Ayt Gmil } \\ 11 & \text { Ayt Bufrah }\end{array}$

$1 \quad$ Ktama

2 Taǵzut

3 Ayt Bušibet

5 Ayt Bunsar

6 Ayt Bšir

7 Zerqet

8 Ayt Úennus

9 Ayt Seddat

11 Ayt Bufrah
12 Targist

13 Ayt Mezduy

14 Ayt Eammart

15 Ayt Ițteft

16 Ibeqquyen

17 Ayt Weryagel

18 Ayt Temsaman

19 Ayt Tuzin

20 Ayt Wlišek

21 Tafersit

22 Ayt Srid
23 Igzennayen

24 Ibḍalsen

25 Ayt Buyehya

26 Iznasen

27 Ikebdanen

28 Iqelciyen

29 Wlad Settut

30 Ayt Buzeggu

31 Gersif

32 Tawrirt 